\title{
KOMPETENSI MANAJERIAL KEPALA SEKOLAH UNTUK MENINGKATKAN MUTU GURU
}

\author{
FATIMAH FARAH SABRINA, ASTUTI DARMIYANTI, MUHAMAD TAUFIK BK \\ Universitas Singaperbangsa Karawang \\ Email: Fatimahfarah28@gmail.com, astuti.damaryanti@fai.unsika.ac.id, \\ muhammad.taufik@unsika.ac.id
}

(Article History)

Received October 27, 2020; Revised November 12, 2020; Accepted November 16, 2020

\begin{abstract}
:
This study tries to describe the managerial competence of school principals, to describe the quality of teachers in schools (MTS), then to analyze the managerial competencies of principals to improve teacher quality both partially and simultaneously in Karawang, Wadas. Qualitative methods, namely through observation, interviews and documentation. The results of this study indicate that the principal's managerial competence to improve the overall quality of teachers is going well, the principal makes every effort to carry out his duties as a leader or manager. Syllabus and curriculum programs that have gone well as planned since the founding of the school. Then the concept of the principal leads to vision mission of the school, and apply open managerial concepts in management. The principal always works together, coordinates with all related elements and always provides motivation to teachers and students. Constantly monitoring, evaluating and evaluating and controlling school equipment
\end{abstract}

Keywords: Managerial Competence, Teacher Quality, Principal Managerial

\section{PENDAHULUAN}

M anajemen merupakan hal yang sangat penting dalam semua bidang kehidupan. Dengan manajemen, kinerja dalam sebuah organisasi yang dapat berjalan dengan maksimal. Demikian juga dengan lembaga pendidikan. Menurut Jafar, Yusrizal, dan Khairuddin (2018), “Manajemen dapat diartikan sebagai ilmu atau profesi karena ilmu sebagai manajemen yang dipandang suatu bidang pengetahuan secara sistematik berusaha memahami bagaimana seseorang yang bekerja sama."

Keberhasilan di lembaga pembelajaran disebabkan adanya pengelolaan sekolah serta handal di dalam bidang lembaga kependidikan. Mengutip pernyataan Wahyudi (2012, h.16), yakni “Manajemen merupakan hal yang sangat bernilai dalam suatu kehidupan bahkan dengan manajemen kinerja organisasi dapat berjalan dengan maksimal, demikian juga lembaga pendidikan".

Jafar, Yusrizal, dan Khairuddin (2018) menunjukkan bahwa kepala sekolah memainkan peran yang sangat penting. Lebih lanjut dikutip sebagai berikut:

"Kepala sekolah adalah peran yang memanfaatkan secara efektif dan efisien semua profesional di sekolah untuk mencapai tujuan yang terbaik 
untuk penyelenggaraan pendidikan yang sesuai. Sekolah sebagai lembaga pendidikan formal, mengemban tugas untuk mencapai tujuan instisional yang berimplikasi terhadap kecapaiannya tujuan pembelajaran nasional".

Sekolah bagaikan institusi pembelajaran yang perlu dibangun dan dikelola dengan baik, sehingga menjadi lembaga pembelajaran yang berkualitas. Oleh karena itu, diperlukan kepemimpinan yang mampu me-manage dan mengarahkan bawahannya untuk mencapai tujuan lembaga. Dengan memiliki kompetensi manajerial, maka kepala sekolah sebagai puncak tertinggi dalam struktur organisasi sekolah akan membawa pengaruh pada pegawai di tingkat bawah. Oleh karenanya, kepala sekolah akan menjadi penentu dalam pencapaian keberhasilan lembaga pendidikan. Nurdin (2015) mengemukakan bahwa "Kepala sekolah bertanggung jawab memelihara dan memotivasi guru, peserta didik, staf administrasi agar bersedia dan mampu melaksanakan ketentuan peraturan yang berlaku di sekolah, dan harus bisa melaksanakan peran kepala sekolah dan memiliki kemampuan di bidang manajemen sekolah."

Peraturan Menteri Nomor 13 Tahun 2007 tentang Standar Kepala Sekolah dikutip sebagai berikut "Ada 5 kompetensi dasar yang harus dimiliki oleh kepala sekolah yaitu kepribadian, manajerial, kewirausahaan, supervisi, dan sosial." Pendidikan kepemimpinan menggambarkan adanya komponen pendidikan yang sangat berperan untuk peningkatkan mutu lembaga pendidikan. Oleh karena itu, diperlukan kemampuan mengkoordinir dalam mencapai tujuan pendidikan. Sebagai konsep dasar 5 keahlian kepala sekolah tersebut hendaknya dibahas secara terpisah, akan tetapi untuk pengalamannya yaitu salah satu yang dibutuhkan mengarahkan untuk merencanakan, mengorganisir, menggerakkan dan mengatur para guru agar mempunyai kinerja yang baik untuk melakukan tugasnya.

Kompetensi manajerial merupakan salah satu upaya untuk menggapai tujuan pendidikan dan peningkatan mutu pembelajaran di sekolah. Untuk itu dibutuhkan pemberdayaan kepala sekolah pada aspek kompetensi tersebut. Kepala sekolah harus mampu memimpin dan mengelola sumber daya seara optimal. Hal ini bukan pekerjaan mudah. Namun perlu kemampuan manajerial dan kepemimpinan yang baik. Kompetensi manajerial kepala sekolah mulai dari menyusun perencanaan sekolah, mengembangkan organisasi sekolah, mendayagunakan sumber sekolah, sehingga dapat melaksanakan pengawasan aktivitas sekolah sesuai dengan standar pengawasan yang telah berlaku. Sesuai pendapat Karweti (2010, h. 85) yang mengatakan bahwa

"Kepala sekolah memiliki kompetensi manajerial yang sangat tinggi untuk dibutuhkan dalam membangun sekolah berkualitas karena kepala sekolah sebagai pemegang otoritas dalam pelaksanaan pendidikan di sekolah perlu memahami proses pembelajaran serta menjalankan tugasnya dengan baik, sehingga proses penyelenggaraan pembelajaran 
di sekolah dapat berjalan sesuai dengan upaya untuk pencapaian tujuan pembelajaran secara efektif dan efesien".

Manajemen berasal dari kata to manage yang memiliki arti yaitu mengurus, mengatur, melaksanakan, mengelola dan memperlakukan, sehingga kata "pembelajaran" berkaitan dengan kata "pengajaran" dalam bentuk bahasa Arab diujarkan "tarbiyah wa ta' lim" sedangkan "pembelajaran islam" dalam bentuk bahasa Arab diujarkan "tarbiyah islamiyah" secara khusus pembelajaran islam merupakan yang dibentuk dengan karakter muslim. Berdasarkan hakikatnya manajemen yakni pengaturan terdapat dalam Al- Qur'an seperti Firman Allah swt dalam Q.S. AI-Sajdah ayat 05, sebagai berikut:

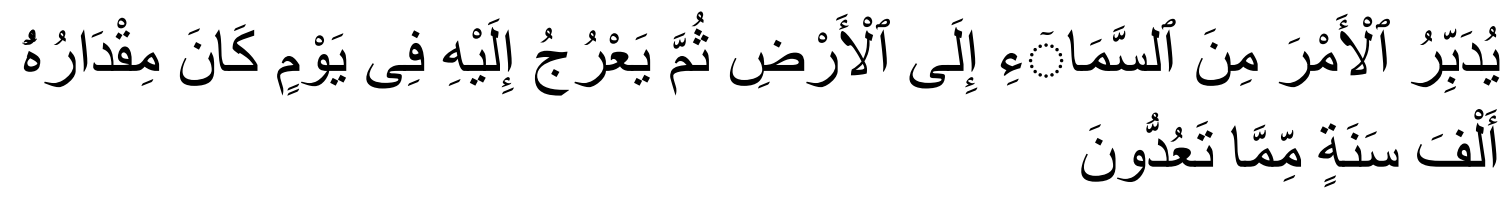

“(5) Dia mengatur urusan dari langit ke bumi, kemudian (urusan) itu naik kepadaNya dalam satu hari yang kadarnya adalah seribu tahun menurut perhitunganmu"

Kompetensi (LOMA dalam Kompri, 2017, h. 2) merupakan sebagai macammacam pribadi sebagai seorang pekerja memanfaatkan untuk mencapai kinerja yang superior, pada dasarnya dengan kepribadian termasuk sifat, motif-motif, sistem nilai, sikap, pengetahuan dan keterampilan. Kompetensi dapat mengarahkan tingkah laku, dan tingkah laku akan menghasilkan kinerjanya. Sebagaimana dikatakan oleh Rosidah (2003) bahwa kompetensi sebagai karakterikstik yang mungkin pegawai memanfaatkan kinerja superiror untuk pekerjaanya.

Kompetensi adalah salah satu aspek penentu keberhasilan sesuatu profesi ataupun pekerjaan. Kompetensi merupakan seperangkat pengetahuan, keterampilan, serta sikap yang wajib dimiliki, dihayati, serta oleh guru dalam melaksanakan tugas keprofesionalan. Kepala sekolah bisa diartikan sebagai cerminan tentang apa yang sepatutnya bisa dilakukan seorang kepala sekolah dalam melakukan pekerjaannya, baik berupa aktivitas, berperilaku maupun hasil yang bisa ditunjukkan. Penulis mengartikan bahwa kompetensi manajerial kepala sekolah dan kompetensi seorang guru sangatlah berarti untuk dimiliki oleh seorang kepala sekolah dan juga seorang guru. Kepala sekolah serta guru memiliki peran yang begitu besar terhadap dunia pembelajaran yaitu untuk mencerdaskan anak bangsa yang sesuai dengan tujuan pembelajaran nasional.

Usman (2011, h. 5) mengatakan "Kepala sekolah diharapkan melaksanakan tugas pokok dan fungsi sebagai manajer dan leader. Efektivitas kepemimpinan kepala sekolah tergantung kepada kemampuan bekerja sama dengan seluruh warga sekolah, serta kemampuannya mengendalikan pengelolaan sekolah untuk menciptakan proses belajar mengajar". 
Menurut Priansa (2017, h. 126, 135) yang dikutip sebagai berikut:

“Kompetensi manajerial menggambarkan manajemen proses untuk mencapai hasil mendayagunakan sumber daya yang tersedia secara produktif. Kompetensi manajerial selaku kepala sekolah dapat menjalankan yaitu menyusun perencanaan madrasah untuk berbagai tingkatan perencanaan,mengembangkan organisasi sekolah yang sesuai kebutuhan, kepemimpinan sekolah sebagai pendayagunaan sumber daya secara optimal, pengelolaan terhadap perubahan dan juga pengembangan sekolah yang sesuai menuju organisasi pendidikan secara efisien, menciptakan budaya sekolah secara kondusif maupun inovatif sebagai pendidikan sesuai peserta didik dan mengelola guru dan staf selaku pendayagunaan sumber daya manusia secara optimal...kemampuan menyusun perencanaan sekolah untuk berbagai tingkatan, kemampuan mengembangkan organisasi sekolah sesuai kebutuhan, kemampuan pemimpin guru dan staf dalam rangka memperdayagunakan sumber daya manusia (SDM) secara optimal dan Kemampuan mengelola guru dan staf dalam rangka memperdayagunaan SDM secara optimal. Kompetensi pada hakekatnya yaitu kemampuan seseorang untuk melaksanakan suatu pekerjaan, kegiatan, sikap yang hasilnya bisa ditunjukkan, serta bisa diukur tingkatan keberhasilannya."

Dengan perkembangan yang semakin pesat pada level sekolah, sudah jelas bahwa kepala sekolah yang sedang mengelola sekolah dituntut agar semakin memperluas, membaharui dan memperdalam mengetahuan serta kompetensi kepala sekolah dalam memimpin sekolah untuk mencapai tujuan pendidikan dengan baik. Oleh sebab itu, kompetensi menentukan sikap serta kinerja seorang pula memutuskan apakah seseorang melakukan pekerjaannya. Kompetensi manajerial kepala sekolah mengorganisasi serta meningkatkan sumber daya sekolah untuk menghasilkan area belajar yang efektif serta efisien. Kompetensi adalah salah satu aspek penentu keberhasilan sesuatu profesi ataupun pekerjaan. Penulis mengartikan bahwa kompetensi manajerial kepala sekolah dan kompetensi seorang guru penting untuk dimiliki oleh kepala sekolah dan guru. Kepala sekolah serta guru memiliki peran besar terhadap dunia pendidikan, yakni menciptakan generasi cerdas yang sesuai dengan tujuan pembelajaran nasional. Dalam Standar Nasional Pendidikan Peraturan Pemerintah Republik Indonesia Nomor 19 Tahun 2005, Pasal 1 Ayat 1, 2 dan 3 mengenai penjaminan mutu dan tujuan yang berbunyi:

"Setiap satuan pendidikan pada jalur formal maupun non formal wajib melakukan penjaminan mutu pendidikan yang bertujuan memenuhi dan melampaui standar nasional yang dilakukan secara bertahap, sistematis dan terencana dalam suatu program penjaminan mutu yang memiliki target dan kerangka waktu yang jelas".

Mutu ditentukan berdasarkan pertimbangan (kriteria) intrinsik dan ekstrinsik berlandaskan kriteria intrinsik, kualitas pembelajaran merupakan produk pembelajaran yaitu "manusia yang terdidik" sesuai dnegan standar ideal. 
Berdasarkan kriteria ekstrinsik, pembelajaran adalah instrumen untuk mendidik "tenaga kerja" yang terlatih dalam artian deskriptif, kualitas ditentukan berdasarkan kondisi kenyataan. Sebagaimana menurut Danim (2010) yang dikutip bahwa "Guru tidak mampu menghasilkan proses pembelajaran yang berkualitas dapat disebabkan oleh rendahnya kompetensi yang dimiliki guru, ketidakmauan dan ketidakmampuan guru menyesuaian wawasan dan kompetensi dapat menyebabkan rendahnya mutu pendidikan di sekolah."

Peraturan Pemerintah Nomor 19 Tahun 2005 tentang Standar Nasional Pendidikan menuntut guru untuk memiliki tingkat kompetensi yang tinggi, Tugas utama guru akan efektif jika guru memiliki derajat profesionalitas tertentu yang tercemin dari kompetensi, kemahiran, kecakapan atau keterampilan yang memenuhi standar mutu atau norma etik tertentu. Kompetensi guru yaitu kecakapan, kemampuan dan keterampilan yang dimiliki oleh seseorang yang bertugas mendidik siswa agar mempunyai kepribadian, yang luhur dan mulia sebagaimana tujuan pendidikan menurut Mulyasa (2007) yang mengatakan bahwa "Kompetensi guru merupakan perpaduan antara kemampuan personal, keilmuan, teknologi, sosial dan spiritual yang secara menyeluruh membentuk kompetensi standar profesi guru". Seorang guru membutuhkan kompetensi yang baik, sehingga dapat mengembangkan dan penyajian materi pembelajaran yang aktual dengan menggunakan berbagai pendekatan, metode, dan teknologi pembelajaran terkini di sekolah yang akan berdampak positif bagi peningkatan proses pembelajaran sendiri, serta dapat menghasilkan mutu pendidikan yang tinggi.

Selain kompetensi seorang guru sebagai tenaga pendidik membutuhkan sertifikasi tenaga pendidik. Sertifikasi merupakan pengakuan secara resmi kompetensi seseorang untuk memangku suatu jabatan profesional. Seorang guru wajib memiliki sertifikasi pendidik yang diperoleh melalui pendidikan profesi. Pengakuan guru sebagai tenaga yang profesional dibuktikan dengan sertifikasi pendidik (Undang-undang Nomor 14 Tahun 2005). Mulyasa (2007) mengatakan "Sertifikasi guru dapat diartikan sebagai suatu proses pemeberian pengakuan bahwa seseorang telah memiliki kompetensi untuk melaksanakan pelayanan pendidikan pada satuan pendidikan tertentu, setelah lulus uji kompetensi yang diselenggarakan oleh lembaga sertifikasi".

Kompetensi dan sertifikasi sangat dibutuhkan seorang tenaga pendidik di sekolah. Menurut Danim (2010), "Pengembangan dan peningkatan kompetensi guru yang sudah memiliki sertifikat pendidik dilakukan untuk menjaga agar kompetensi keprofesionalannya tetap sesuai dengan perkembangan ilmu pengetahuan, teknologi, seni,dan budaya”. Oleh sebab itu, maka dapat dinyatakan bahwa mutu tenaga pendidik merupakan seorang guru menjadi suatu prioritas untuk meningkatkan upaya peningkatan kualitas mutu pendidikan di sekolah, untuk dibutuhkan berbagai kegiatan yang meningkatkan mutu tenaga pendidik salah 
satunya dengan peningkatan kompetensi guru dan sertifikasi guru sebagai tenaga pendidik di sekolah.

Surdawan (2006, h. 53) mengatakan:

"Mutu guru pada konteks pendidikan yang mengacu dan masukan, proses serta berdampak dengan kualitas yang dapat dilihat dari berbagai yaitu, Pertama, kondisi yang baik maupun masukan sumber daya manusia seperti kepala sekolah, guru, staf, tata usaha serta siswa. Kedua, memahami dengan adanya kriteria yang terjadi pada kurikulum serta prasarana sekolah. Ketiga, memenuhi kriteria yang sebagai perangkat lunak dengan adanya peraturan disekolah dan struktur organisasi. Keempat, kualitas yang bersifat dengan harapan sebagai kebutuhan seperti visi, misi dan ketekunan".

Berdasarkan hasil dari observasi di MTs Annur Lemahabang Karawang kepala sekolah sebagai manajer dalam mengelola sekolah yang merupakan faktor kunci keberhasilan termasuk dalam meningkatkan kualitas guru. Untuk mengembangan dan meningkatkan kualitas guru harus lebih memahami yang telah diarahkan oleh kepala sekolah. Ketika kepala sekolah telah memahami yang dapat diartikan sebuah manajemen pendidikan, maka kepala sekolah diharapkan dapat merencanakan, melaksanakan dan mengawasi program sekolah secara efektif. Kepala sekolah memiliki peran yang penting untuk meningkatkan kualitas guru agar bekerja dengan baik. Seharusnya kepala sekolah membentuk manajerial yang baik dengan sistem pengaturan tugas yang sangat jelas. Sistem manajerial yang baik bisa dibentuk dengan adanya gaya kepemimpinan kepala sekolah yang tepat. Dengan kompetensi yang dimiliki kepala sekolah seharusnya dapat menggunakan gaya kepemimpinan yang tepat agar peningkatkan kualitas guru mencapai tujuan yang diharapkan. Dengan demikian tujuan penelitian ini adalah untuk mengetahui kompetensi manajerial kepala sekolah dalam peningkatan mutu guru di MTs Annur Lemahabang Karawang.

\section{METODE PENELITIAN}

Metodologi penelitian yang digunakan yaitu penelitian kualitatif sebagai metode deskriptif. Penelitian ini merupakan teknik pengumpulan data seperti observasi, wawancara dan dokumentasi yang menggunakan latar belakang ilmiah dan fenomena. Lokasi penelitian di MTs Annur Lemahabang Karawang. Wawancara dilakukan dengan beberapa orang yaitu 1 kepala sekolah dan 5 guru. Teknik pengambilan data menggunakan observasi secara langsung dan wawancara dengan informan. Metode pengumpulan data menggunakan dokumentasi. Penelitian ini dilakukan secara khusus yaitu wawancara mengenai kompetensi manajerial kepala sekolah serta peningkatan kualitas guru. Teknik analisis data yang digunakan adalah secara deskriptif. 


\section{HASIL PENELITIAN DAN PEMBAHASAN}

\section{Deskripsi Kompetensi Manajerial Kepala Sekolah dalam Meningkatkan Kualitas} guru di Sekolah Mts. Annur Lemahabang Karawang

Hasil penelitian menujukkan bahwa meningkatkan kompetensi manajerial sebagai kepala sekolah yang telah diberikan untuk mengagendakan beberapa kegiatan, salah satunya berkaitan dengan pelaksanaan program sekolah secara baik. Sedangkan kepala sekolah harus mempunyai kemampuan serta sertifikat dan sudah sesuai dengan peraturan sertifikat dalam tenaga pendidik.

Guru sebagai faktor penting dan utama terhadap tenaga pendidik, sangat berpengaruh dalam menghasilkan kualitas proses pembelajaran. Guru merupakan pemimpin kelas membutuhkan kompetensi dan sertifikat sebagai seorang tenaga pendidik. Guru yang profesional terbentuk dari adanya kompetensi yang dimiliki guru, serta memiliki sertifikat yang baik dari pemerintah sebagai seorang tenaga pendidik. Guru membutuhkan kemampuan yang baik dalam mengelola dengan proses pembelajaran, adanya kompetensi dan sertifikat pada diri guru akan memudahkan dalam pengelolaan program kegiatan di sekolah. Mutu guru yang berkualitas baik, memiliki pola pemikiran mulai dari kreatif, inovatif dan memiliki keterampilan yang baik dalam menjalankan dan mengelola program kegiatan yang maksimal.

Guru yang memiliki tugas sebagai pengajar dan pendidik, tentu harus mengetahui tugasnya untuk menyampaikan segala bentuk ilmu atau materi pelajaran yang telah ditetapkan oleh kurikulum. Dalam peraturan pemerintah (PP) Nomor 74 Tahun 28 tentang Guru Pasal 3 Ayat 1 menjelaskan bahwa "Kompetensi merupakan separangkat pengetahuan, keterampilan dan perilaku yang harus dimiliki dan dihayati".

Agar perlu kita ketahui bahwa pada kenyataannya, faktor-faktor tersebut masih banyak guru yang belum dengan adanya kualitasnya setidaknya harus sesuai dengan peningkatan kualitasnya secara pendidikannya sebagai seorang guru harus mempunyai tanggung jawab terhadap pengajarannya sebagaimana yang sudah disyaratkan, akan tetapi kualitas dirinya belum mencapai tingkatan yang dibutuhkan untuk setiap bidang profesi. Dengan demikian guru mempunyai kegiatan program yang harus dilaksanakan terhadap menyampaikan ilmu, serta seorang guru masih banyak yang kurang mendapatkan kesempatan agar bisa lebih meningkat dalam rendahnya kesadaran guru.

\section{Pendukung dan Penghambat dalam Kompetensi Manajerial Kepemimpinan untuk Peningkatan mutu guru di MTs Annur Lemahabang Karawang.}

Hasil penelitian menunjukkan bahwa faktor pendukung yang ada yaitu, dukungan dari yayasan, wakil kepala madrasah dan kemampuan komunikasi kepala sekolah dalam pembinaan guru. Faktor pendukung kepemimpinan kepala sekolah adalah dukungan dari yayasan agar sekolah MTs Annur semakin berkembang, dan dukungan dari wakil kepala madrasah sendiri. Terpenuhinya target kebutuhan guru merupakan harapan yang diidamkan oleh kepala sekolah dengan berupaya 
mewujudkan sekolahnya sebagai basis pengetahuan, termasuk untuk meningkatkan kualitas pendidikan agar lebih baik.

Pendukung serta penghambat kompetensi manajerial kepemimpinan untuk peningkatan kualitas guru, dapat dideskripsikan dengan faktor penghambat yang yaitu kurangnya maksimalnya motivasi guru, dan kurangnya waktu dalam penyampaian pengajaran. Sebagaimana menurut Kompri (2017) banyak faktor penghambat kompetensi manajerial sebagai kepemimpinan untuk peningkatkan mutu guru, seperti kurangnya optimalnya motivasi guru dan terbatasnya waktu untuk jam pengajaran, sehingga waktu untuk berdiskusi dengan rekan sangat minim.

Rendahnya kualitas pada saat mengajar, banyak sebagian guru tidak menjalankan amanah dengan baik. Berdasarkan dalam bidang masing-masing yang sudah terjadinya dengan menurunnya motivasi guru saat mengajar di kelas harus bisa lebih semaksimal mungkin agar bisa melaksanakan pembelajaran, menilai hasil pembelajaran dan melakukan bimbingan dengan baik. Motivasi seorang guru yang timbulnya pada diri sendiri, secara sadar untuk menghadapi hal penting dalam kegiatan belajar mengajar sebagai dorongan siswa agar memberikan semangat untuk menjalankan sebuah pendidikan yaitu belajar di kelas.

Motivasi terdiri dari 2 jenis yaitu motivasi instriksik dan motivasi ekstrinsik yang memiliki cara sebagai kualitas pada saat mengajar. Oleh karena itu, motivasi instriksik berfungsi sebagai dalam diri setiap individu sudah ada dorongan untuk melakukan sesuatu. Sebagai contoh seorang siswa melakukan belajar, karena hakikatnya ingin mendapat pengetahuan, nilai atau keterampilan agar dapat berubah tingkah lakunya secara konstruktif, tidak karena tujuan lain. Itulah sebabnya motivasi instrinsik dapat juga dikatakan sebagai bentuk motivasi yang didalamnya aktivitas belajar dimulai dan diteruskan berdasarkan suatu dorongan dari dalam diri dan secara mutlak terkait dengan aktivitas belajarnya. Kemudian, motivasi ekstrinsik didalamnya bentuk motivasi aktivitas yang dari belajar berdasarkan dorongan dari luar tidak secara mutlak berkaitan dengan aktivitas belajar. Sebagai contoh seorang itu belajar, karena tahu besok akan ujian dengan harapan mendapatkan nilai yang baik, sehingga akan dipuji oleh temannya, atau oleh teman spesialnya. Jadi yang penting bukan karena belajar untuk mendapat pengetahuan tetapi ingin mendapatkan nilai yang baik dan pujian. Jadi dilihat dari segi tujuan kegiatan yang dilakukannya tidak secara langsung dengan esensi apa yang dilakukannya.

Kompetensi manajerial kepemimpinan untuk peningkatan berkualitas guru di MTs. Annur yang meliputi sebagai berikut: faktor pendukung yaitu memiliki dukungan atau dorongan melalui seorang yayasan di sekolah yang sudah berkembang sampai saat ini, serta dukungan dari beberapa staf lainnya sudah berkembang di dalam bidang masing-masing, sehingga mengenai kehidupan di sekolah semakin banyak pengurus lainnya agar bisa tersusun program secara baik. Sebagai seorang pemimpin kepala sekolah sudah mempunyai tugas dan tanggung jawab berkaitan 
dengan dukungan dari wakil kepala sekolah yang sudah membantu berdasarkan program kegiatan yang telah ada untuk menunjukkan dari beberapa guru lainnya agar bisa melaksanakan program kegiatan sejak komunikasi yang telah disampaikan.

\section{PENUTUP/SIMPULAN}

Kepemimpinan kepala sekolah dapat memberikan peningkatkan kualitas guru di MTs Annur Lemahabang Karawang. Dalam mewujudkan visi, misi dan tujuan melakukan program-program, dijelaskan secara terarah dan bertahap. Kepala sekolah mempunyai kemampuan manajemen kepemimpinan yang sangat mencukupi agar bisa mengelola sekolah dengan baik. Kemudian beberapa guru mengadakan program-program yang telah direncanakan seperti pelatihan/mengikuti seminar. Faktor pendukung kompetensi manajerial kepemimpinan untuk peningkatkan mutu di sekolah MTs Annur Lemahabang Karawang, yaitu dukungan dari yayasan agar sekolah MTs Annur semakin meningkat dan berkembang, memiliki dukungan wakil kepala sekolah terhadap kepemimpinan yang cukup membantu dalam mengarahkan guru. Faktor penghambat meliputi kurangnya motivasi guru dalam mengajar, hal ini berkaitan dengan pemberian gaji pokok dan kebijakan pada guru yang berkualitas.

Kemampuan manajerial terhadap kepemimpinan kepala sekolah dapat meningkatkan kualitas guru di MTs Annur Lemahabang Karawang. Kepala sekolah harus mengoptimalkan kemampuan manajerial secara keseluruhan agar bisa mencapai sekolah yang berkualitas. Alangkah baiknya untuk bisa memperluas dan mencari pengetahuan sebagaimana kemampuan manajerial agar bisa lebih kompeten secara semaksimal. Kemudian, dalam peningkatkan mutu guru sebaiknya guru saling terbuka dengan kepala sekolah agar bisa menjalankan tugasnya secara maksimal kembali yang berkaitan dengan pengembangan kurikulum.

\section{DAFTAR PUSTAKA}

Danim. (2010). Profesionalisasi dan Etika Profesi Guru. Bandung: Alfabeta.

Jafar, Z., Yusrizal, \& Khairuddin. (2018). Kompetensi Manajerial Kepala Sekolah dalam Meningkatkan Kinerja Guru pada SMP Islam Terpadu Al-Fityan Kabupaten Aceh Besar. Jurnal Magister Administrasi Pendidikan: Program Pascasarjana Unsyiah Kuala, 6(1), 36-44.

Karweti. (2010). Kontribusi Manajerial Kepala Sekolah dan Sistem Kepegawaian Terhadap kinerja Mengajar Guru. Jurnal Penelitian Pendidikan, 11(2), 77-89.

Kompri. (2017). Standarisasi Kepala Sekolah. Jakarta: Kencana.

Mulyasa. (2007). Menjadi Guru Profesional Menciptakan Pembelajaran Kreatif dan menyenangkan. Bandung: Rosdakarya.

Nurdin, D. (2015). Kompetensi Manajerial Kepala Sekolah dalam Membangun Iklim Sekolah dan Kepuasaan Guru di Sekolah Dasar. Sekolah Dasar: Kajian Teori Dan Praktik Pendidikan, 24(1), 45-56. Retrieved from 
http://journal2.um.ac.id/index.php/sd/article/view/1352/712

Priansa, D. J. (2017). Menjadi Kepala Sekolah dan Guru Profesional Konsep Peran dan Strategis Pengembangnya. Bandung: CV Pustaka Setia.

Rachmawati, Y. (2013). Pengaruh Kepemimpinan Kepala Sekolah terhadap Kinerja Guru. Jurnal Pendidikan Ekonomi IKIP, 01(01), 19-28.

Rosidah. (2003). Manajemen Sumber Daya Manusia. Yogyakarta: Graha IImu.

Surdawan, D. (2006). Visi Baru Manajemen Sekolah dari Unit Birokrasi ke Lembaga Akademik. Jakarta: PT. Bumi Aksara.

Usman, D. (2011). Buku Kerja Kepala Sekolah. jakarta: Pusat Pengembangan Tenaga kependidikan badan PSBMP dan PMP Kementrian Pendidikan Nasional.

Wahyudi. (2012). Kepemimpinan Kepala Sekolah dalam Organisasi Pembelajaran. Bandung: CV. Alfabeta. 